\title{
Adsorpsi Asam Humat pada Zeolit Alam yang Dimodifikasi dengan $\mathrm{TiO}_{2}$
}

\author{
Upita Septiani ${ }^{1 *}$, Fiska Julian Tasari ${ }^{1}$, Zilfa $^{2}$ \\ ${ }^{1}$ Laboratorium Kimia Material, Jurusan Kimia, Fakultas Matematika dan Ilmu Pengetahuan Alam, \\ Universitas Andalas \\ ${ }^{2}$ Laboratorium Kimia Analitik, Jurusan Kimia, Fakultas Matematika dan Ilmu Pengetahuan Alam, \\ Universitas Andalas
}

Corresponding Author:

Upita Septiani

upitaseptiani@sci.unand.ac.id

Received: January 2020

Accepted: March 2020

Published: March 2020

(C) Upita Septiani et al. This is an open-access article distributed under the terms of the Creative Commons Attribution License, which permits unrestricted use, distribution, and reproduction in any medium, provided the original author and source are credited.

\begin{abstract}
This research modified natural zeolite with $\mathrm{TiO}_{2}$ synthesized by the sol-gel process which was applied as a humic acid adsorbent. The purpose of this study was to coat natural zeolites with $\mathrm{TiO}_{2}$ to increase the adsorption capacity of natural zeolites as humic acid adsorbents. The natural zeolite powders were obtained from Kabupaten Solok, West Sumatra, based on Xray Fluorescence $(\mathrm{XRF})$ analysis, the ratio of silica/alumina (Si/Al) was 4.35, indicating that natural zeolite was clinoptilolite zeolite. Scanning Electron Microscopy (SEM) analysis showed natural zeolite has a rough surface with closed pores while zeolite coated with $\mathrm{TiO}_{2}$ (zeolite/ $/ \mathrm{TiO}_{2}$ ) has a homogeneous, smooth surface with open pore. The results of the Energy Dispersive X-Ray Spectroscopy (EDS) analysis showed that the level of $\mathrm{TiO}_{2}$ was $7.1 \%$, this result showed that $\mathrm{TiO}_{2}$ has been coated on the surface of the zeolite. Natural zeolite and zeolite/ $/ \mathrm{TiO}_{2}$ were applied as humic acid adsorbents. Maximum adsorption capacity of natural zeolites and zeolites $/ \mathrm{TiO}_{2}$ were $0.2787 \mathrm{mg} / \mathrm{g}$ and $1.199 \mathrm{mg} / \mathrm{g}$, respectively.
\end{abstract}

Keywords: Adsorption, humic acid, coating, sol-gel, zeolit/TiO,

\section{Pendahuluan}

Air merupakan komponen yang sangat diperlukan dalam kehidupan sehari-hari, air digunakan dalam memenuhi kebutuhan mencuci, mandi, memasak dan minum. Masyarakat Indonesia pada umumnya menggunakan air tanah dan air permukaan seperti air sumur, air sungai dan air dari perusahaan air minum (PAM) untuk memenuhi kebutuhan airnya. Air yang didapatkan dari alam ini banyak mengandung asam humat yang merupakan senyawa kompleks, campuran komponen organik makromolekul yang terbentuk secara alami.
Kehadiran asam humat pada air minum dapat berpengaruh pada rasa, warna dan bau serta dapat bertindak sebagai substrat untuk pertumbuhan mikroorganisme ${ }^{[1]}$.

Asam humat merupakan senyawa organik alami yang dapat dijumpai pada perairan dan tanah. Asam humat dikelompokkan menjadi tiga subkategori yaitu: (a) asam fulvat, merupakan senyawa humat bersifat hidrofilik, yang larut dalam air pada semua $\mathrm{pH}$, (b) asam humat, merupakan senyawa humat yang larut pada $\mathrm{pH}$ tinggi dan tidak larut pada $\mathrm{pH}$ asam $(\mathrm{pH}<2)$. (c) humin, merupakan senyawa humat yang tidak larut dalam air pada semua nilai 
pH. Asam humat itu sendiri tidak berbahaya bagi kesehatan manusia, namun reaksinya dengan desinfektan berbasis halogen agen menghasilkan berbagai produk samping seperti munculnya desinfeksi trihalomethanes (TMHs). Senyawa TMHs ini dapat memicu pertumbuhan kanker, menyebabkan masalah reproduksi dan menimbukan masalah pertumbuhan. Berbagai metode telah dikembangkan untuk menghilangkan asam humat dalam pengolahan air, seperti biofilter, oksidasi fotokalitik dan adsorpsi. Proses adsorpsi merupakan metode menghilangkan komponen dengan proses penyerapan oleh suatu padatan dan tidak menghasilkan efek samping. Banyak adsorben telah diselidiki untuk digunakan dalam adsorpsi asam humat seperti karbon aktif, zeolit, resin, tanah liat, dan oksida besi[2]-[5].

Zeolit merupakan mineral kristal alumina silika tetrahidrat berpori yang mempunyai struktur kerangka tiga dimensi, terbentuk dari tetrahedral $\left[\mathrm{SiO}_{4}\right]^{4^{--}}$dan $\left[\mathrm{AlO}_{4}\right]^{4-}$ yang saling terhubungkan dengan atom-atom oksigen sedemikian rupa, sehingga membentuk kerangka tiga dimensi yang memiliki ronggarongga yang di dalamnya terisi ion-ion logam. Biasanya ion-ion yang terdapat dalam rongga tersebut adalah alkali atau alkali tanah dan molekul air yang dapat bergerak bebas. Dari struktur tersebut, zeolit dapat digunakan sebagai adsorben, penukar ion dan katalis. Zeolit alam memiliki muatan negatif pada kerangka strukturnya, hal ini dapat mempengaruhi aplikasinya sebagai adsorben. Untuk meningkatkan sifat permukaannya sebagai adsorben, zeolit alam dapat dimodifikasi dengan surfaktan kationik. Liu, $(2014)^{[3]}$ melakukan penelitian pelapisan zeolit alam Australia dengan $\mathrm{TiO}_{2}$ untuk penyerapan asam humat. Zeolit yang dilapisi dengan $\mathrm{TiO}_{2}$ mempunyai muatan permukaan partikel positif, sehingga molekul asam humat dengan mudah terserap pada permukaan zeolit dengan interaksi elektrostatik. Pelapisan zeolit dengan $\mathrm{TiO}_{2}$ tersebut dapat meningkatkan efisiensi dalam penyerapan asam humat hingga $80 \%[3],[6],[7]$.
Indonesia mempunyai deposit zeolit alam cukup besar dan kemurniannya cukup tinggi, zeolit alam sangat ramah lingkungan dengan harga tidak mahal dan menunjukkan adanya potensi yang bagus dalam penanganan masalah air. Fajri, (2016) ${ }^{[8]}$ telah melakukan penelitian tentang zeolit alam yang berasal dari Kabupaten Solok Sumatera Barat, zeolit alam ini merupakan jenis zeolit klinoptilolit. Zeolit alam Kabupaten Solok ini belum banyak dipelajari dan dimanfaatkan ${ }^{[8],[9] \text {. }}$

Pada penelitian ini, zeolit alam Kabupaten Solok dimodifikasi dengan $\mathrm{TiO}_{2}$. Pelapisan zeolit alam Kabupaten Solok dengan $\mathrm{TiO}_{2}$ yang disintesa dengan metode sol-gel serta kemampuan adsorpsi asam humat oleh zeolit alam Kabupaten Solok dan zeolit alam yang dimodifikasi dengan $\mathrm{TiO}_{2}$ akan dipelajari.

\section{Metode Penelitian}

\section{Bahan kimia}

Bahan-bahan yang digunakan dalam penelitian ini antara lain zeolit alam Kabupaten Solok Sumatera Barat, titanium tetraisopropoksida (TTIP), asam humat, etanol p.a (Merck), akuades, dan $\mathrm{NaOH}$ (Merck).

\section{Peralatan}

Peralatan yang digunakan antara lain peralatan gelas, lumpang dan alu, oven, timbangan analitik, hotplate stirrer, shaker, X-ray Fluorescence (XRF) (PAnalytical EPSILON-3), X-ray Difraction (XRD) (Philip X pert Powder Type PW4030/60), Scanning Electron MicroscopyEnergi Dispersive X-Ray Spectroscopy (SEM-EDS) (JOEL tipe JSM-6390LA), Fourier Transform Infrared (FTIR) (Unican Mattson Mod 7000 FTIR), dan Spektrofotometer Visible tipe Spektronik 20.

\section{Prosedur penelitian}

\section{Preparasi zeolit alam dan zeolit/TiO}

Bubuk zeolit alam ditumbuk hingga halus, setelah itu diayak dengan saringan berukuran 125 mesh. Sebelum zeolit alam diaktivasi, zeolit alam dikarakterisasi dengan XRF untuk mengetahui komponen penyusunnya, 
kemudian diaktivasi pada suhu $450^{\circ} \mathrm{C}$. Sebanyak $10 \mathrm{~g}$ zeolit alam yang telah diaktivasi didispersi dalam larutan yang mengandung 957,5 mL etanol dan 7,5 mL air, kemudian larutan suspensi diaduk pada $500 \mathrm{rpm}$. Nanopartikel $\mathrm{TiO}_{2}$ disiapkan dengan metode sol-gel, dengan cara hidrolisis TTIP. Variasi volume TTIP 1,75 mL (Zeolit/TiO $2 \mathrm{~A}$ ) dan TTIP 5,25 mL (zeolit/ $/ \mathrm{TiO}_{2} \mathrm{~B}$ ) ditambahkan ke dalam etanol hingga volume menjadi $35 \mathrm{~mL}$, campuran hasil hidrolisis ini langsung ditambahkan ke suspensi zeolit secara perlahan. Kemudian didiamkan selama 3 jam, lalu disaring dengan kertas Whatman No. 42. Padatan yang tersaring dikeringkan dalam oven pada suhu $80^{\circ} \mathrm{C}$ selama 5 jam, lalu dikalsinasi selama 3 jam pada suhu $450^{\circ} \mathrm{C}$. Zeolit alam dan zeolit/ $/ \mathrm{TiO}_{2}$ yang terbentuk dikarakterisasi dengan FTIR, XRD dan SEMEDS.

\section{Pembuatan larutan induk asam humat}

Larutan induk asam humat konsentrasi 100 $\mathrm{mg} / \mathrm{L}$ dibuat dengan menimbang asam humat standar $10 \mathrm{mg}$ dan dilarutkan ke dalam $\mathrm{NaOH}$ 0,1 M, diencerkan hingga tanda batas pada labu ukur $100 \mathrm{~mL}$. Lalu dibuat variasi konsentrasi (5, 10, 15, 20 dan 25) mg/L dalam labu ukur 100 $\mathrm{mL}$ dengan $\mathrm{NaOH}$ 0,1 M hingga tanda batas. Kemudian dilakukan pengukuran absorbansi pada rentang panjang gelombang 200-400 nm, sehingga didapatkan panjang gelombang maksimum, lalu diukur absorbansi masingmasing larutan pada panjang gelombang maksimum tersebut.

\section{Pengaruh waktu kontak terhadap adsorpsi asam humat}

Untuk menentukan waktu kontak maksimum adsorpsi asam humat oleh zeolit alam dan zeolit $/ \mathrm{TiO}_{2}$ hasil sintesis, maka ke dalam masing-masing erlenmeyer dimasukkan $0,6 \mathrm{~g}$ zeolit alam dan zeolit/ $/ \mathrm{TiO}_{2}$ lalu ditambahkan 30 $\mathrm{mL}$ asam humat dengan konsentrasi $20 \mathrm{mg} / \mathrm{L}$ (diambil salah satu konsentrasi yang ada dalam variasi konsentrasi). Pengadukan dilakukan selama variasi waktu kontak $(15,30,45,60$, dan 75) menit dengan kecepatan $250 \mathrm{rpm}$. Campuran disaring dan filtratnya dianalisis dengan Spektrofotometer UV-Vis pada panjang gelombang maksimum.

\section{Adsorpsi asam humat oleh zeolit alam dan zeolit/TiO 2 hasil sintesis}

Untuk menentukan kapasitas adsorpsi zeolit alam dan zeolit $/ \mathrm{TiO}_{2}$ hasil sintesis, maka ke dalam erlenmeyer masing-masing dimasukkan zeolit alam dan zeolit/ $\mathrm{TiO}_{2} \quad 0,6$ g, lalu ditambahkan $30 \mathrm{~mL}$ asam humat dengan variasi konsentrasi $(5,10,15,20$ dan 25) mg/L. Pengadukan dilakukan dengan waktu kontak optimum dengan kecepatan $250 \mathrm{rpm}$. Campuran disaring dan filtratnya dianalisis dengan Spektrofotometer UV-Vis pada panjang gelombang maksimum.

\section{Hasil dan Diskusi}

\section{Analisis X-Ray Flourescence (XRF) zeolit alam}

Karakterisasi X-Ray Flourescence dilakukan untuk mengetahui komponen penyusun zeolit alam, dari Tabel 1 dapat dilihat unsur-unsur penyusun zeolit alam. Rasio perbandingan $\mathrm{Si} / \mathrm{Al}$ adalah parameter yang penting untuk membedakan jenis zeolit alam, dari Tabel 1 didapatkan rasio perbandingan unsur $\mathrm{Si} / \mathrm{Al}$ yaitu 4,35. Rasio tersebut berada pada rentang rasio zeolit klinoptilolit, yaitu berdasarkan teoritis perbandingan ratio $\mathrm{Si} / \mathrm{Al}$ zeolit klinoptilolit berada pada rentang $4-4,5^{[9]}$.

\section{Analisis Fourier Transform InfraRed (FTIR) zeolit alam dan zeolit/ $\mathrm{TiO}_{2}$ hasil sintesis}

Berdasarkan Gambar 1 zeolit alam, mempunyai pita serapan pada daerah bilangan gelombang $3626 \mathrm{~cm}^{-1}$ yang merupakan regangan gugus $\mathrm{OH}$ dari molekul $\mathrm{H}_{2} \mathrm{O}$. Gambar 1(a) zeolit alam, (b) zeolit $/ \mathrm{TiO}_{2} \mathrm{~A}$ dan (c) zeolit/ $/ \mathrm{TiO}_{2} \mathrm{~B}$ menunjukkan adanya pita serapan dengan puncak yang kuat pada bilangan gelombang 1010-1019 $\mathrm{cm}^{-1}$ merupakan regangan kerangka utama penusun zeolit $\mathrm{Si}(\mathrm{Al})-\mathrm{O}-\mathrm{Si}(\mathrm{Al})$. Ikatan pada serapan gelombang 777-780 $\mathrm{cm}^{-1}$ merupakan serapan regangan simetris $\mathrm{T}-\mathrm{O}$ $(\mathrm{T}=\mathrm{Al}$ atau $\mathrm{Si})$, sedangkan bilangan gelombang $555-567 \mathrm{~cm}^{-1}$ ialah menunjukkan vibrasi tekuk ikatan $\mathrm{T}-\mathrm{O}(\mathrm{T}=\mathrm{Si} \text { atau } \mathrm{Al})^{[10]}$. 
Tabel 1. Hasil XRF zeolit alam

\begin{tabular}{cc}
\hline Unsur & Kandungan (\%) \\
\hline $\mathrm{Si}$ & 71,348 \\
$\mathrm{Al}$ & 16,398 \\
$\mathrm{Ca}$ & 0,56 \\
$\mathrm{Mg}$ & 1,775 \\
$\mathrm{Fe}$ & 2,515 \\
$\mathrm{Mn}$ & 0,009 \\
$\mathrm{~V}$ & 0,043 \\
$\mathrm{~K}$ & 4,527 \\
$\mathrm{Cl}$ & 0,015 \\
\hline
\end{tabular}

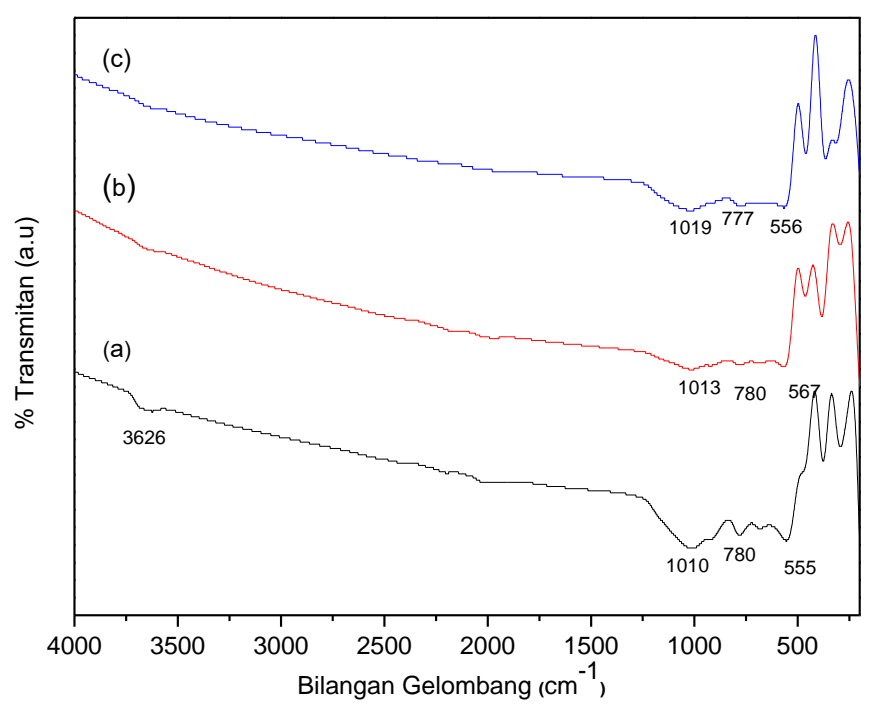

Gambar 1. Spektrum FTIR (a) Zeolit alam (b) Zeolit/TiO ${ }_{2} \mathrm{~A}$ (c) Zeolit/TiO $2 \mathrm{~B}$. Keterangan: Zeolit/TiO $2 \mathrm{~A}$ $=$ Zeolit $/ \mathrm{TiO}_{2}$ dengan volume TTIP 1,75 mL dan Zeolit $/ \mathrm{TiO}_{2} \mathrm{~B}=$ Zeolit $/ \mathrm{TiO}_{2}$ dengan volume TTIP 5,25 $\mathrm{mL}$.

\section{Karakterisasi X-Ray Difraction (XRD) zeolit alam dan zeolit/ $\mathrm{TiO}_{2}$}

Analisis ini dilakukan untuk mendapatkan informasi tentang fasa yang terbentuk, pola XRD zeolit/ $\mathrm{TiO}_{2} \mathrm{~A}$ dan zeolit $/ \mathrm{TiO}_{2} \mathrm{~B}$ dibandingkan dengan pola XRD standar zeolit alam dan $\mathrm{TiO}_{2}$. Gambar 2 menunjukkan bahwa zeolit alam yang digunakan zeolit klinoptilolit dan zeolit mordenit. Adanya zeolit klinoptilolit ditandai kemunculan puncak pada $20,8^{\circ}, 36,4^{\circ}$, dan $68,0^{\circ}$ dan zeolit mordenit yang muncul pada puncak $34,8^{\circ}, 39,3^{\circ}$ dan $59,8^{\circ}$. Gambar 2 memperlihatkan tidak adanya perubahan pola XRD yang signifikan antara zeolit alam dan zeolit/ $\mathrm{TiO}_{2}$ hasil sintesis. Berdasarkan data $2 \theta$, pada zeolit $/ \mathrm{TiO}_{2} \mathrm{~A}$ muncul puncak pada $25,23^{\circ}$, $37,6^{\circ}$ dan $62,2^{\circ}$ dan untuk zeolit/ $\mathrm{TiO}_{2} \mathrm{~B}$ muncul puncak pada $25,2^{\circ}, 47,9^{\circ}$ dan $62,3^{\circ}$, menunjukkan terbentuknya fasa $\mathrm{TiO}_{2}$ anatase (berdasarkan data ICSD 9852). Hal serupa dengan penelitian yang telah dilakukan oleh Liu (2014) ${ }^{[3]}$ yang menyatakan, puncak $\mathrm{TiO}_{2}$ 
tidak muncul pada pola XRD karena $\mathrm{TiO}_{2}$ yang ditambahkan sangat sedikit.

\section{Analisis Scanning Electron Microscopy-Energi Dispersive X-Ray Spectroscopy (SEM-EDS) zeolit Alam zeolit $/ \mathrm{TiO}_{2}$ hasil sintesis}

Gambar 3 menunjukkan morfologi zeolit alam terdiri dari lamelar-lamelar berlapis yang kasar, dan sela-sela lamelar tersebut terdapat rongga pori-pori yang tertutup, sedangkan pada zeolit/ $\mathrm{TiO}_{2} \mathrm{~B}$ terlihat perubahan yang signifikan antara morfologi permukaan zeolit alam dengan zeolit yang sudah dilapisi dengan $\mathrm{TiO}_{2}$ (zeolit/ $\mathrm{TiO}_{2} \mathrm{~B}$ ) hasil sintesis. Dari Gambar 3 terlihat jelas permukaan zeolit yang sudah dilapisi $\mathrm{TiO}_{2}$ merupakan lamelar-lamelar yang lebih halus dan disela-selanya terdapat poripori zeolit yang lebih terbuka.

Berdasarkan Tabel 2, hasil analisis Energy Dispersive X-Ray Spektroscopy (EDS) zeolit/ $/ \mathrm{TiO}_{2} \mathrm{~B}$ membuktikan bahwa zeolit sudah terlapisi oleh $\mathrm{TiO}_{2}$. Data EDS tersebut menyatakan kandungan $\mathrm{TiO}_{2}$ pada zeolit/ $\mathrm{TiO}_{2} \mathrm{~B}$ adalah $7,13 \%$, hal ini sesuai dan mendukung analisis XRD yang menyatakan munculnya fasa $\mathrm{TiO}_{2}$ pada $2 \theta ; 25,2^{\circ}, 47,9^{\circ}$, dan $62,3^{\circ}$, meskipun puncak-puncak $2 \theta$ tersebut tidak tampak pada gambar pola XRD karena puncaknya sangat kecil dikarenakan prekursor TTIP yang digunakan juga sangat sedikit.

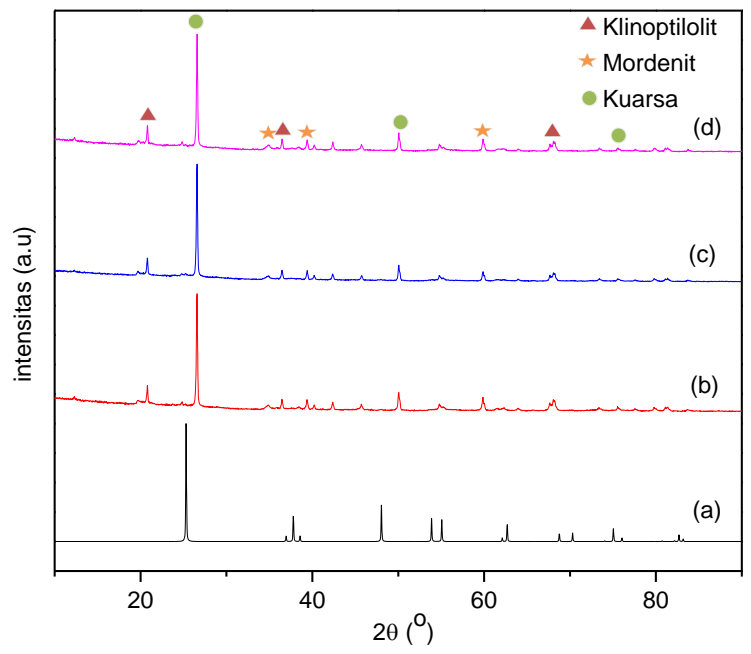

Gambar 2. Pola XRD (a) $\mathrm{TiO}_{2}$ standar (b) Zeolit alam (c) Zeolit/ $/ \mathrm{TiO}_{2} \mathrm{~A}$ (d) Zeolit/ $\mathrm{TiO}_{2} \mathrm{~B}$.
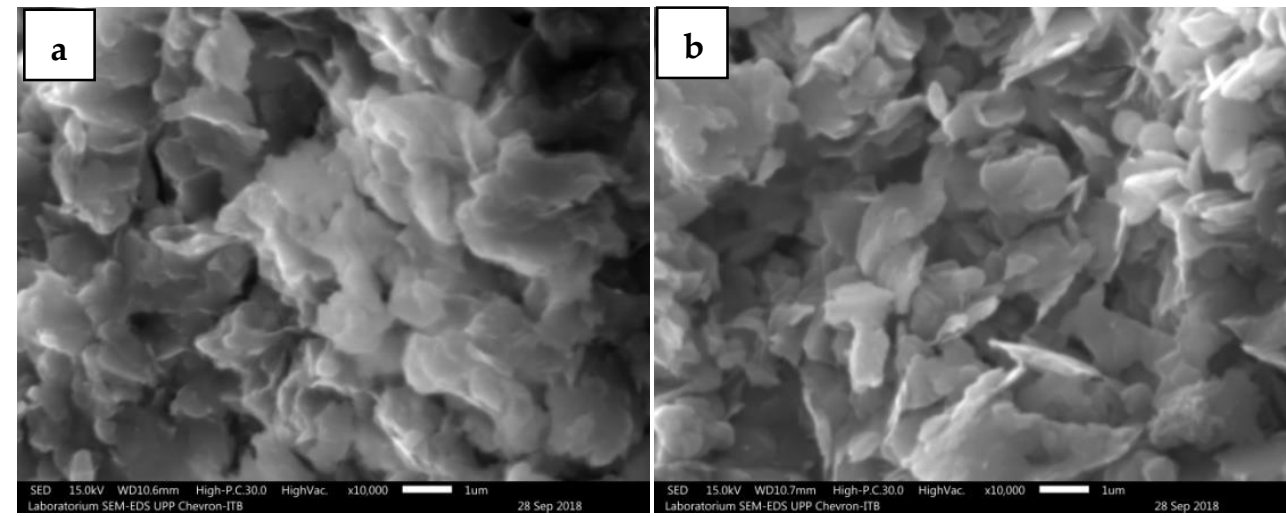

Gambar 3. Morfologi permukaan (a) Zeolit alam (b) Zeolit/ $\mathrm{TiO}_{2} \mathrm{~B}$ dengan perbesaran 10.000x. 
Tabel 2. Hasil Analisis EDS

\begin{tabular}{ccc}
\hline \multirow{2}{*}{ Komponen } & Zeolit & Zeolit/ $\mathbf{T i O}_{\mathbf{2}} \mathbf{B}$ \\
\cline { 2 - 3 } & (\% massa) & (\% massa) \\
\hline $\mathrm{C}$ & 4,75 & 5,37 \\
$\mathrm{O}$ & 50,68 & 46,30 \\
$\mathrm{Al}$ & 11,09 & 10,80 \\
$\mathrm{Si}$ & 31,16 & 27,50 \\
$\mathrm{~K}$ & 2,32 & 2,90 \\
$\mathrm{Ti}$ & - & 7,13 \\
& 100 & 100 \\
\hline
\end{tabular}

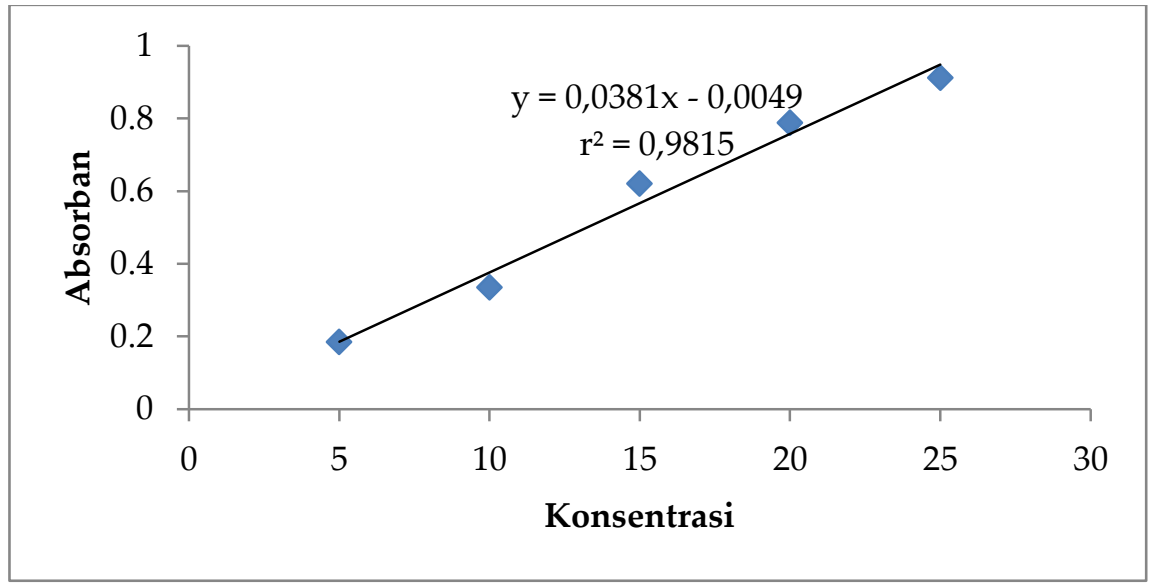

Gambar 4. Kurva standar asam humat pada variasi konsentrasi (5, 10, 15, 20 dan 25) mg/L.

Tabel 2 juga menunjukkan zeolit alam memiliki komponen utama kerangka penyusunnyanya adalah unsur silika dan alumina, dengan rasio perbandingan $\mathrm{Si} / \mathrm{Al}=2,8$. Perbandingan rasio $\mathrm{Si}$ dan Al ini menunjukkan zeolit alam yang digunakan tergolong ke dalam zeolit silika sedang yang berada pada rentang rasio 2-5. Hasil EDS ini sesuai dengan hasil XRF yang menunjukkan bahwa zeolit alam yang digunakan dalam penelitian ini termasuk pada jenis zeolit dengan kadar silika sedang. Tabel 2 juga memperlihatkan adanya kenaikkan dan penurunan pada persen massa komponen penyusun zeolit dan zeolit/ $/ \mathrm{TiO}_{2} \mathrm{~B}$ hal ini dikarenakan sampelnya memang berbeda dan titik tembak elektron untuk masing-masing sampel juga tidak sama.

\section{Pengukuran serapan asam humat pada variasi konsentrasi}

Pada pengukuran larutan asam humat menggunakan spektrofotometer UV-Vis pada panjang gelombang maksimum $215 \mathrm{~nm}$, nilai absorban yang didapatkan pada konsentrasi 5 $\mathrm{mg} / \mathrm{L}, 10 \mathrm{mg} / \mathrm{L}, 15 \mathrm{mg} / \mathrm{L}, 20 \mathrm{mg} / \mathrm{L}$ dan $25 \mathrm{mg} / \mathrm{L}$ berturut-turut adalah 0,$184 ; 0,334 ; 0,620 ; 0,787$ dan 0,911 (Gambar 4). Nilai absorban asam humat berbanding lurus dengan konsentrasi, semakin besar konsentrasi semakin besar absorban yang terukur. 
Penentuan waktu kontak maksimum zeolit alam dan zeolit/ $\mathrm{TiO}_{2} \mathrm{~B}$ hasil sintesis

Gambar 5 menunjukkan bahwa semakin lama proses adsorpsi maka kapasitas adsorpsi zeolit dan zeolit/ $/ \mathrm{TiO}_{2} \mathrm{~B}$ semakin meningkat. Kapasitas adsorpsi terus mengalami kenaikan dari waktu 15-75 menit, kapasitas adsorpsi zeolit dan zeolit/ $/ \mathrm{TiO}_{2} \mathrm{~B}$ tertinggi berada pada menit ke 75 yaitu berturut-turut $0,3005 \mathrm{mg} / \mathrm{g}$ dan $0,35 \mathrm{mg} / \mathrm{g}$.
Kapasitas adsorpsi zeolit alam dan zeolit/ $\mathrm{TiO}_{2} \mathrm{~B}$ hasil sintesis

Gambar 6 memperlihatkan bahwa pengaruh konsentrasi asam humat terhadap kapasitas adsorpsi asam humat, dimana semakin tinggi konsentrasi asam humat maka semakin besar pula kapasitas adsoprsinya pada setiap variasi konsentrasi $^{[11]}$

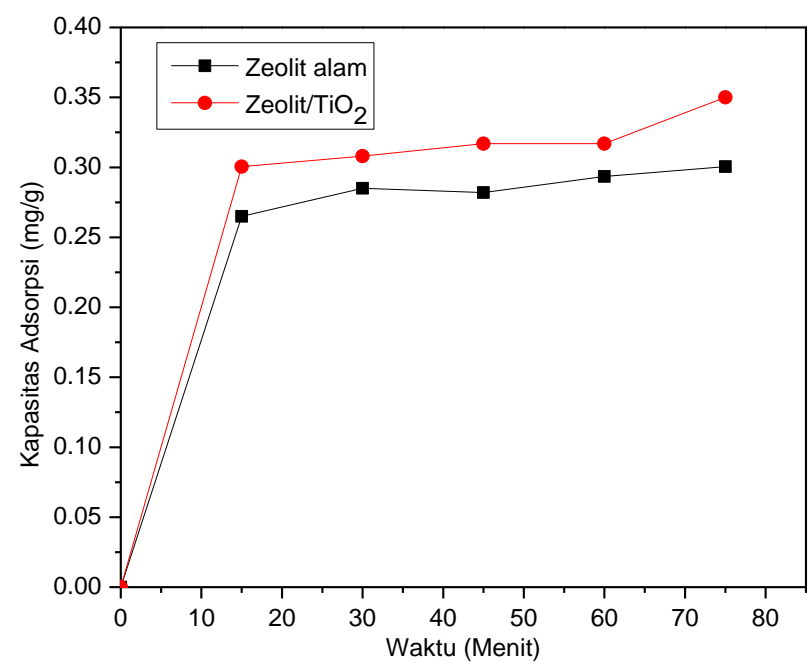

Gambar 5. Kapasitas adsorpsi Zeolit alam dan $\mathrm{Zeolit} / \mathrm{TiO}_{2} \mathrm{~B}$ pada variasi waktu kontak.

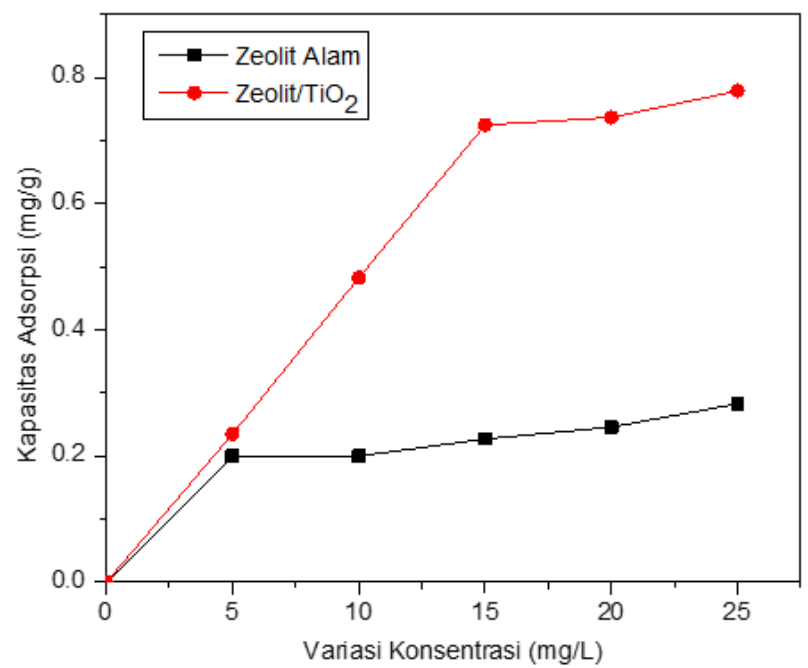

Gambar 6. Kapasitas adsorpsi Zeolit alam dan Zeolit/TiO2B pada variasi konsentrasi. 
Dari data pengaruh konsentrasi terhadap adsorpsi asam humat terlihat bahwa zeolit/ $\mathrm{TiO}_{2} \mathrm{~B}$ memiliki kemampuan menyerap asam humat lebih besar dibandingkan zeolit alam. Adsorpsi asam humat pada permukaan padatan merupakan proses yang kompleks yang tergantung pada sifat permukaan zeolit alam dan sifat larutan asam humat itu sendiri, asam humat terdiri dari campuran senyawa yang memiliki fungsional grup bersifat asam seperti gugus fenolik dan karboksilat. Sedangkan zeolit alam memiliki muatan negatif pada kerangka strukturnya, sehingga gaya elektrostatik menjadi rendah serta adanya interaksi dipol yang kuat antara zeolit alam dengan air. Zeolit yang dilapisi dengan $\mathrm{TiO}_{2}$ yang mempunyai muatan permukaan partikel positif, sehingga molekul asam humat dengan mudah terserap pada permukaan zeolit/ $/ \mathrm{TiO}_{2} \mathrm{~B}$ dengan interaksi elektrostatik ${ }^{[3]}$.

\section{Analisis isoterm adsorpsi asam humat oleh} zeolit alam dan zeolit/ $\mathrm{TiO}_{2} \mathrm{~B}$

Dari Tabel 3 dapat diperoleh nilai $\mathrm{R}^{2}$ isoterm adsorpsi Langmuir dan Freundlich.
Berdasarkan data tersebut nilai $\mathrm{R}^{2}$ isoterm adsorpsi Langmuir zeolit alam dan zeolit/ $/ \mathrm{TiO}_{2} \mathrm{~B}$ berturut-turut yaitu 0,9654 dan 0,6309, sedangkan nilai $\mathrm{R}^{2}$ isoterm adsorpsi Freundlich zeolit dan zeolit/ $\mathrm{TiO}_{2} \mathrm{~B}$ berturut-turut 0,7626 dan 0,9318 . Dari nilai $\mathrm{R}^{2}$ yang telah didapatkan, hasil tersebut menunjukkan bahwa zeolit alam mengikuti model isoterm Langmuir dan zeolit/ $\mathrm{TiO}_{2} \mathrm{~B}$ mengikuti model isoterm Freundlich, karena masing-masing $\mathrm{R}^{2}$ mendekati 1 (Gambar 7). Zeolit alam mengikuti model Langmuir yang artinya telah terjadi adsorpsi yang homogen pada permukaan zeolit yang membentuk lapisan satu lapis (monolayer) dan terjadinya ikatan kimia antara asam humat dengan zeolit alam. Sedangkan zeolit/ $\mathrm{TiO}_{2} \mathrm{~B}$ mengikuti model isoterm adsorpsi Freundlich, dimana pada model ini terjadinya adsorpsi multilayer asam humat pada permukaan zeolit/ $\mathrm{TiO}_{2} \mathrm{~B}^{[12]}$.

Tabel 3. Isoterm adsorpsi Langmuir Freundlich

\begin{tabular}{ccccccc}
\hline \multirow{2}{*}{ Adsorben } & \multicolumn{3}{c}{ Langmuir } & \multicolumn{3}{c}{ Freundlich } \\
\cline { 2 - 6 } & $\mathrm{R}^{2}$ & $\mathrm{~K}$ & $\mathrm{Q} \max$ & $\mathrm{R}^{2}$ & $\mathrm{nf}$ & $\mathrm{K}$ \\
\hline Zeolit & 0,9654 & 0,52 & 0,2787 & 0,7626 & 5,1 & 0,126 \\
Zeolit/TiO $\mathrm{B}$ & 0,6309 & 0,0089 & 1,199 & 0,9318 & 1,3 & 0,075 \\
\hline
\end{tabular}
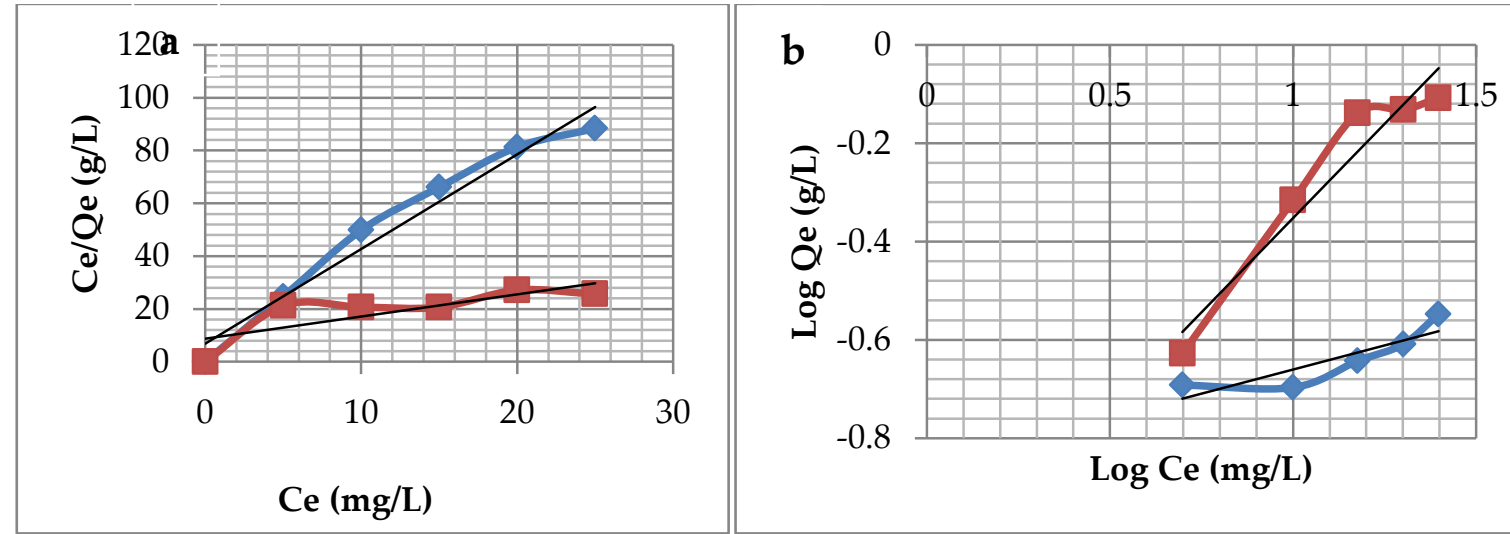

Gambar 7. Isoterm adsorpsi (a) Langmuir (b) Freundlich. 


\section{Kesimpulan}

Berdasarkan analisis XRF zeolit alam Kabupaten Solok merupakan zeolit klinoptilolit dengan rasio perbandingan Si/Al 4,35. Dari analisis XRD dan SEM-EDS zeolit alam ini dapat dikompositkan dengan $\mathrm{TiO}_{2}$, dimana kadar $\mathrm{TiO}_{2}$ dalam zeolit/TiO2B adalah $7,1 \%$. Zeolit alam Kabupaten Solok dan zeolit/ $/ \mathrm{TiO}_{2} \mathrm{~B}$ diaplikasikan sebagai adsorben asam humat, kapasitas adsorpsi maksimum zeolit alam dan zeolit/ $\mathrm{TiO}_{2} \mathrm{~B}$ berturut-turut $0,2787 \mathrm{mg} / \mathrm{g}$ dan $1,199 \mathrm{mg} / \mathrm{g}$. Analisis Isoterm adsorpsi menunjukan zeolit alam mengikuti model persamaan Langmuir dengan nilai $\mathrm{R}^{2}$ adalah 0,9654 sedangkan zeolit/ $\mathrm{TiO}_{2} \mathrm{~B}$ mengikuti model persamaan Freunlich dengan nilai $\mathrm{R}^{2}$ 0,9318 .

\section{Daftar Pustaka}

1. Said, N. I., Kesehatan masyarakat dan teknologi peningkatan kualitas air. Direktorat Teknologi Lingkungan Deputi Bidang Teknologi INF, (1999).

2. Rahmawati, A., Isolasi dan karakterisasi asam humat dari tanah gambut. J. Phenom., 2(1): (2011).

3. Liu, S., Lim, M. \& Amal, R., $\mathrm{TiO}_{2}$-coated natural zeolite: Rapid humic acid adsorption and effective photocatalytic regeneration. Chem. Eng. Sci., 105: 46-52 (2014).

4. Sun, D. D. \& Lee, P. F., $\mathrm{TiO}_{2}$ microsphere for the removal of humic acid from water: Complex surface adsorption mechanisms. Sep. Purif. Technol., 91: 30-37 (2012).

5. Capone, D. G., Bronk, D. A., Mulholland, M. R. \& Carpenter, E. J., Nitrogen in the marine environment. Elsevier, (2008).

6. Septiani, U., Putri, R. A. \& Jamarun, N., Synthesis of zeolite ZMS-5 from rice husk ash ash as catalyst in vegetable oil transesterification for biodisel production. Der Pharm. Lett., 8(19): 86-91 (2016).

7. Septiani, U., Admi., Afriza, D. \& Yefrida., Effect of cetyltrimethylammonium bromide (CTAB) template on synthesis of zeolitic material from fly ash and application of zeolitic material obtained as an adsorbent of heavy metals $\mathrm{Cd}$ and $\mathrm{Cu}$. Res. J. Chem. Environ., 22(9): 23-26 (2018).

8. Muhammad, L. F., Pemanfaatan zeolit alam sumatera barat sebagai pendukung $\mathrm{TiO}_{2}$ dalam degradasi congo red serta simulasi limbah secara fotolisis. Universitas Andalas, (2016).

9. Las, T. \& Zamroni, H., Penggunaan zeolit dalam bidang industri dan lingkungan. $J$. Zeolit Indones., 1(1): 27-34 (2002).

10. Liu, X., Liu, Y., Lu, S., Guo, W. \& Xi, B., Performance and mechanism into $\mathrm{TiO}_{2} /$ Zeolite composites for sulfadiazine adsorption and photodegradation. Chem. Eng. J., 350: 131-147 (2018).

11. Trivana, L., Sugiarti, A. \& Rohaeti, E., Sintesis zeolit dan komposit seolit/ $/ \mathrm{TiO}_{2}$ dari kaolin serta uji adsorpsi fotodegradasi biru metilena. AlChemy J. Penelit. Kim., 11(2): 147-162 (2015).

12. Alshameri, A., Yan, C. \& Lei, X., Enhancement of phosphate removal from water by $\mathrm{TiO}_{2} /$ Yemeni natural zeolite: Preparation, characterization and thermodynamic. Microporous Mesoporous Mater., 196: 145-157 (2014). 